\title{
Corporate Social Responsibility for Education
}

\author{
Lavinia-Maria Niţulescu, Elena-Alina Hosu
}




\title{
Corporate Social Responsibility for Education
}

\author{
Lavinia-Maria Nițulescu ${ }^{\text {a* }}$, Elena-Alina Hosu ${ }^{b}$ \\ ${ }^{a}$ Educational Sciences Department, UBB University Studies Center from Reșița, Traian Vuia Square, No.1 -4, Reșița, 320 085, Romania \\ ${ }^{b}$ Associated Teacher at the Educational Sciences Department, UBB University Studies Center from Reșița, Traian Vuia Square, No.1-4, Reșița, \\ 320085 , Romania \\ *Corresponding author: lavinia.nitulescu@ubbcluj.ro
}

\section{Abstract}

\section{Keywords:}

corporate social

responsibility (CSR);

responsibility in the field of

education; educational

benefits of social

responsibility projects.
The present article tackles the concept of corporate social responsibility (CSR) in the educational field, from the perspective of the projects achieved in collaboration with the educational institutions and companies and projects focused on the improvement and updating the background of the school units. The necessity to implement projects in the field of education by private companies and public firms is justified by the existence of certain financial deficits in the educational system. The study of documents and of national and international specialised materials in the CSR field reveals the requirement to consult schools in establishing the action directions but also the involvement of the business environment in the adaptation of the educational programs to the needs of the labour market. By means of an inquiry-based questionnaire, applied online to a number of 50 representatives having different levels and profiles within educational institutions in the Western area, both from the rural and the urban environment, we have gathered examples of good practice in assuming the implementation of the social responsibility projects in the field of education, in the Western area of Romania.

\section{Zusammenfasung}

\section{Schlüsselworte:}

sozialen

Verantwortung von

Unternehmen (CSR);

Verantwortung im

Bildungsbereich; pädagogische Vorteile von Projekten der sozialen Verantwortung
Der Artikel befasst sich mit dem Konzept der sozialen Verantwortung von Unternehmen (Corporate Social Responsibility, CSR) für den Bildungsbereich aus der Perspektive von Projekten, die in Zusammenarbeit zwischen Bildungseinrichtungen und Unternehmen durchgeführt werden und sich auf die Verbesserung und Modernisierung der Verhältnisse in Schulen konzentrieren.

Die Notwendigkeit Projekte im Bildungsbereich durch private und öffentliche Unternehmen durchzuführen, ist durch das Bestehen bestimmter finanzieller Mängel im Bildungssystem gerechtfertigt.

Die Untersuchung nationaler und internationaler Fachdokumente und -materialien im Bereich CSR weist auf die Notwendigkeit sich mit den Schulen in der Festlegung der Handelsrichtungen zu beraten, als auch, das engere Einbeziehen der Wirtschaftsvertreter im Anpassungsprozess der Bildungsprogramme an die Anforderungen des Arbeitsmarktes, hin.

Durch die Umfrage, die auf einem Online-Fragebogen basiert, welcher 50. Vertretern von Bildungseinrichtungen aus dem westlichen Landesteil, mit unterschiedlichen Bildungsniveaus und Profilen, sowohl in ländlichen als auch in städtischen Gebieten angewendet wurde, werden Beispiele guter Praxis in der Umsetzung von Projekten der sozialen Verantwortung im Bildungsbereich im Westen Rumäniens angeführt.

\section{Introduction}

The community must adopt "a strong position in favour of learning, school assumes the connection with the community and both admit the fact that school is not the only organisation which has responsibilities towards the little ones" (Senge, 2016a, p. 490). Social responsibility of companies - Corporate social responsibility (CSR) is a concept focused on thetreatment of companies and institutions in a responsible and ethical way (Hopkins, 2016, p. 16). Corporate social responsibility (CSR) is a business model which is self-adjusted and which helps a company to be socially responsible towards it, towards the interested parties and towards the public (www.investopedia.com). In this paper, the denomination of institution is to design all the state or private scholar entities (kindergartens, schools, universities etc.).

\section{Theoretical foundation}

The concept was used for the first time in 1953 by the phrase social responsibilities (SR). Although the authors have tried to state a clearer and more complex definition of the concept, in the specialised literature there is a large terminological variety. We highlighted the analysis made 
by: Philip Kotler, Muhammad Yunus, Michael Hopkins, Michael Porter, which are centred on the fact that CSR means to obtain a profit in moral conditions, next to the community.

Philip Kotler (2005, pp 8-20) defines the concept of CSR as being an engagement in order to improve the living standard of the community. In his opinion, the well-being of society is described in different forms: corporative social responsibility, civic responsibility of the company, corporative charity, corporative donations, relation with the community, business community, development community, corporative responsibility towards education, global civic spirit, corporative social marketing.

Muhammad Yunus (2008) considers that the term social responsibility is built on a foundation of good intentions, although many firms are focused on profit, sometimes unscrupulously obtained by exploiting the human resource. The moment the corporations choose to do a good deed for society, this must be promoted at maximum in order to bring an extra image. By the involvement of CSR, the firm is closer and more attentive to the needs of society. Sustainability, responsibility and transparency are the CSR principles of a corporation which prepares the firm for a clean, healthy and solid future, protecting the natural resources and health of their clients and employees.

Michael Porter (2007) asserts that some firms can contribute in the sustainable development; others are focused on more charity actions. He mentions that it is very important not to make confusions between charity and CSR, because the donations can be done by the economic actors, for a certain social cause, they are just a small component in the complex concept of CSR and the companies are interested in the adoption of a CSR regulated behaviour, as a component part of the organisational strategy in order to become more competitive.

The social responsibility in the field of education and the important role it plays were mentioned in 2006, in the document of the European Commission Communication from the Commission to the European Parliament, the Council and the European Economic and Social Committee, implementing the partnership for growth and jobs: Making Europe a pole of excellence on corporate social responsibility (Brussels, 22.3.2006, COM, 2006). The social responsibility of the companies in the field of education is approached from many perspectives: either centred on the education of employees, by the introduction of the concept in the school curriculum, research projects consortium between the educational units and companies, or focused on the improvement and updating of the environment in the school units.

\section{Research methodology}

Starting from the premises of CSR extension for the benefit of the educational environment, the purpose of this study is to highlight the actions and projects of CSR existing/to be extended in the educational environment. An observatory research was conducted having as objectives: the identification of the degree of the teachers 'acquaintance with the notion of social responsibility of companies; the identification of the initiated actions and of the projects proposals of social responsibility of the companies for education; emphasizing the benefits of CSR. The investigation methods used are: the study of documents and of national and international specialised materials in the targeted field; the inquiry questionnaire for the teachers. The method of the inquiry based questionnaire is a method of investigation in which the research instrument is the questionnaire, supposing a "set of structured questions in a certain succession and in a logical order, addressed in written form to the investigated subjects" (Stan, 2020, p. 629).

The questionnaire, containing a number of 15 questions was applied to a number of 50 representatives having different levels and profiles within educational institutions in the Western area, both from the rural and the urban environment. As regards the content, the factual/administrative questions have aimed aspects connected to age, level of education and the post occupied (closed questions); the opinion questions permitted the identification of subjective aspects - opinions, attitudes referring to the necessity, experience and use of CSR projects in education (open and mixed questions). We have obtained a number of 47 valid answers.

\section{Results}

The study of documents has emphasised the existence of several endeavours for the development of CSR culture. As a consequence of the financial and social crisis in 2008, the tensions in the business and social environment extended. This led to an increase in the number of firms that have changed their organisational culture becoming ethical, with automatic involvement on the educational units as well (Seto-Pamies \& Papaoikonomou, 2016), which started to be consulted regarding the choice of CSR direction, so that the actions of the institutions would be sustainable. The educational institutions, besides the basic, socio-economic and cultural knowledge must put emphasis more on the development of skills for the civic participative involvement. Involving the business environment in the establishment of the curricula can help the educational environment in several directions: alignment of educational programs to the labour market demands, endowment of research laboratories etc, the CSR programs contributing to the reconnection of the economic success with the society progress (Camilleri, 2016).

The data obtained by applying the questionnaire were registered and measured by counting and ordering. The data processing supposed the systematization and presentation 
in tables and statistical graphics based on which the quantitative and qualitative interpretations were achieved.

The results obtained reflect the degree of acquaintance with the notion of social responsibility of companies: of the total of 47 collected answers, a number of 21 answers emphasizes a high or very high acquaintance degree with this concept, 9 answers reveal a superficial knowledge of the term, while 17 answers are limited to little or very little knowledge of the concept (Fig. 1).

Figure 1. The acquaintance degree with the notion of social responsibility

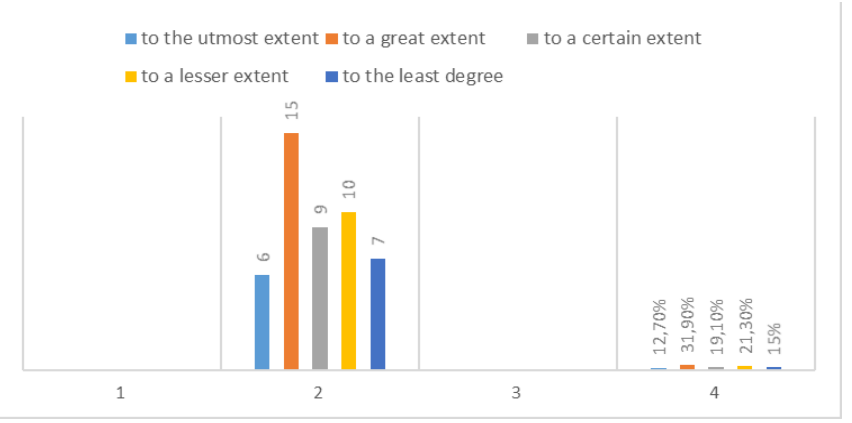

One of the questions addressed has aimed the assignation of the main sources of information in the field of CSR. Most respondents inform themselves first of all by accessing different materials available on the Internet $(42,5)$. The second way of information (in the frequency order of answers) is represented by the information received from the partners of the implemented projects $(21,3 \%)$, followed by the information in the sessions organized by the potential partners (17\%) - Fig. 2).

Figure 2. The sources of information in the field of CSR

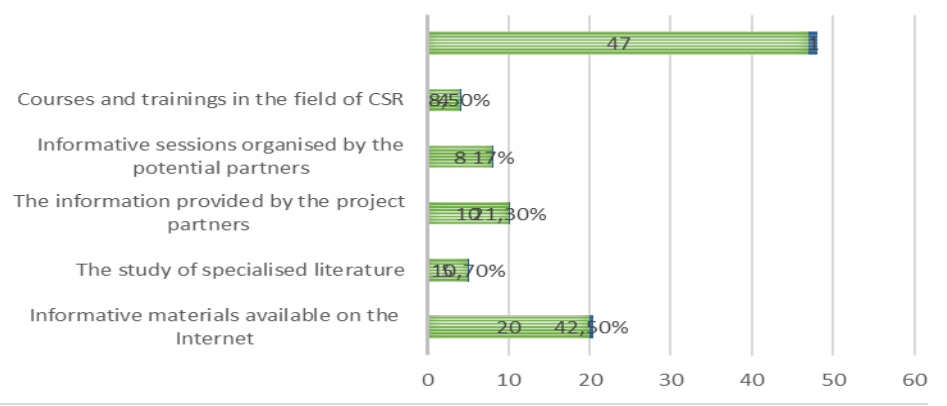

We consider that it is important to present the degree of involvement of school units in the development of activities and CSR projects in collaboration with different companies as part of the social responsibilities of the last ones. A number of 22 respondents have stated that they have collaborated with certain companies for the implementation of CSR projects, 10 respondents do not have knowledge about such collaboration, while a number of 5 respondents have mentioned the fact that there were no collaborations (Fig. 3).
Figure 3. The existence of collaborations with companies

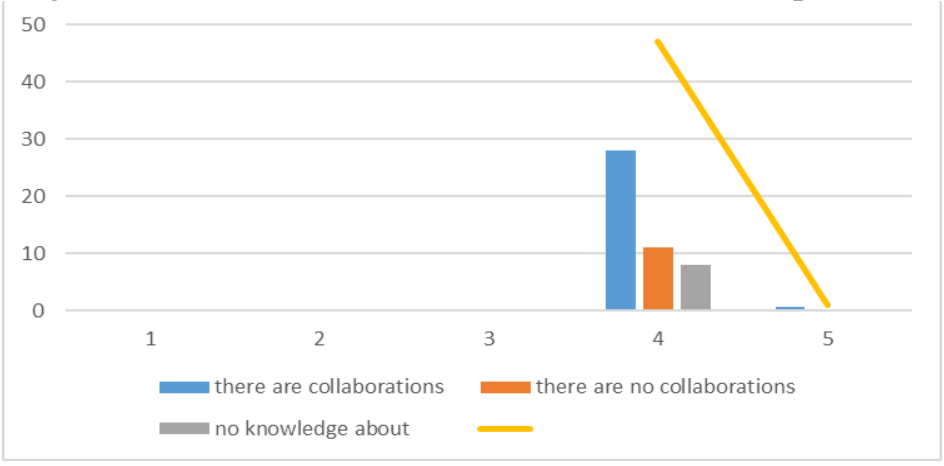

The activities achieved in collaboration with different companies, CSR projects in which there were involved the educational institutions have aimed mainly the following directions-fields (prioritising obtained after the answers centralisation, with minor differences of frequency between the aspects identified) - Table 1:

Table 1. CSR Projects in Western area of Romania

\begin{tabular}{lcc}
\hline CSR Activities/Projects & Proposed & Implemented \\
\hline $\begin{array}{l}\text { Sponsorships of the events } \\
\text { developed in the } \\
\text { institution }\end{array}$ & $\checkmark$ & $\checkmark$
\end{tabular}

Partnerships, practice

tutorials, internship

Environment projects, green campaigns

Contributions to the organization of olympics/ local/regional/national contests

Projects which contribute to the improvement of community life

Projects dedicated to parents (Parents school)

Projects which contribute to the improvement of community life

Projects which aim hygiene and health

Financial education programs

Projects dedicated to the staff formation

Projects which propose the combat of discrimination

Projects dedicated to the formation of didactic staff 
The didactic staffs participating in the study have identified the obvious benefits and improvement that the CSR projects can bring to the educational environment:

- the connection of young people to the economicalsocial reality

- the diversification of the offered programs

- the stimulation of students' creativity

- the identification of the real problems in the educational environment

endowment with didactic equipment and materials necessary for the appropriate development of activities

- studying some fields that the school curriculum does not cover

- collaboration firms - schools in the starting of projects useful for society managers

entrepreneurial education taught in schools by firm

- partnerships and projects outside school for students and teachers

- formation of open mentalities (for teachers, community)

supporting continuous formation of didactic staff updating schools

creation of a coherent framework of good practice.

\section{Conclusions and discussions}

The study aimed to follow the evolution tendency of CSR projects in the Western area. The results obtained have emphasized the existence of projects achieved by school institutions. For the benefit of the educational environment, it is required that the CSR projects should be focused on sustainable activities, with long term positive effects and which can be gradually extended to more educational institutions. The awareness of the benefits that the CSR projects can bring to the educational field determines preoccupations in the sense of expanding collaborations with the aim of increasing the quality in the educational system. It is imperative that the corporate and community social responsibility as regards education focuses on a rise in the number of projects that would support the development of educational components of interest for the respective geographical area. This would take place in the context of assuming responsibility for education while considering the three activity systems involved in this process, "embedded in one another": the class that learns (teachers, students, parents), the school that learns (school inspectors, headmasters, leaders and administrator), the community that learns (community members) (Senge, 2016b, pp.26-35).

Authors note: The authors have equal contributions to this article.

Lavinia-Maria Niţulescu Associate Professor at the Faculty of Psychology and Sciences of Education (Babeş-
Bolyai University, Cluj Napoca, Romania), in the Department of Educational Sciences, University Studies Center from Reșița. Her research and teaching areas are focused on The Theory and Methodology of Evaluation, Teaching Process, Pedagogy of Play.

Elena-Alina Hosu is a Doctoral Student in the field of Educational Sciences. Her interest areas for research are Social Pedagogy and Non-Formal Education. She is also involved in coordinating numerous volunteering actions.

\section{References}

Camilleri, M. A. (2016). Corporate sustainability and responsibility toward education. Journal of Global Responsibility, Vol. 7 No. 1, 56-71 (https://doi.org/10.1108/JGR-08-2015-0015).

Hopkins, M. (2016). CSR and sustainability. From The Margins to the Mainstream. A text book. UK: Greenleaf Publishing Limited.

Kotler, P. (2001). Marketing from A to Z [Marketing de la A la Z]. București: Editura Codecs.

Kotler, P.; Lee, N. (2005). Corporate Social Responsibility: Doing the Most Good for Your Company and Your Cause. USA: John Wiley \& Sons, Inc.

Porter, M. (2007). Doing Well at Doing Good: Do you have a Strategy? Presentation at Willow Creek Association Leadership Summit South Barrington. Illinois August 10 ,

2007

https://www.hbs.edu/faculty/Publication\%20Files/2007 0810_MEP_WillowCreekAssociation_668dc73e-86544719-a674-ac59eb1bfba5.pdf[Accessed at 20.10.2020].

Senge, P. (2016a). Reaching Out To The Community. Building Learning Communities [Să pășim către comunitate. Cultivarea comunităţilor care învaţăa. In Senge, P. (coord.) Schools That Learn, [Şcoli care invaţă]. Bucureşti: Editura Trei, 489-495.

Senge, P. (2016b). Reference Points. The Idea Of Learning School [Ideea de școală care învață]. In Senge, P. (coord.) Schools That Learn, [Şcoli care invaţă]. Bucureşti: Editura Trei, 15-35.

Seto-Pamies, D. \& Papaoikonomou, E. (2016). A Multilevel Perspective for the Integration of Ethics, Corporate Social Responsibility and Sustainability (ECSRS) in management education. Journal of Business Ethics, Vol. 136, No. 3, 523-538. https://www.jstor.org/stable/24736146?seq=1 [Accessed at 20.10.2020].

Stan, C. (2020). The Management of Research Projects [Managementul proiectelor de cercetare]. In Albulescu, I., Catalano, H. (coord.) Syntheses of general pedagogy. Guide for the preparation of tenure, finalization and second degree exams - teachers of all specializations. [Sinteze de pedagogie generală. Ghid pentru pregătirea examenelor de titularizare, 
definitivare și gradul II - profesori de toate specializările]. București: Didactica Publishing House. Yunus, M. (2008). Creating a world without poverty. Social business and the future of capitalism. Global urban development, Volume 4 Issue 2 November 2008, 2126 ***https://eurlex.europa.eu/LexUriServ/LexUriServ.do?uri=COM:2 006:0136:FIN:en:PDF[Accessedat 10.10.2020]. www.investopedia.com[Accessedat 10.10.2020]. 